\title{
Role of climatic factors in the incidence of dengue in Port Sudan City, Sudan
}

Elsiddig Noureldin ${ }^{1}$ and Lynn Shaffer ${ }^{2}$

${ }^{1}$ National Center for Disease Control and Prevention (NCDC), Ministry of Health, Jazan, Saudi Arabia (Correspondence to: Elsiddig Noureldin: siddignoureldin@hotmail.com). ${ }^{2}$ Trinity Health System, Mount Carmel Health System, Columbus, United States of America

\begin{abstract}
Background: Dengue fever outbreaks have occurred in Port Sudan City, Sudan, during the last 2 decades. Climatic factors may play a role in dengue incidence.

Aims: This study aimed at discribing the relationship between climatic factors and dengue fever incidence in Port Sudan during 2008-2013.

Methods: This ecological study entailed secondary data analysis of dengue fever cases and climate information to explore which climatic factors predict the incidence of dengue fever. The Wilcoxon rank sum test and multiple linear regression examined the association between number of dengue fever cases and climatic factors during lag times of 1-6 months.

Results: Relative humidity and maximum and minimum temperatures were correlated with dengue incidence in Port Sudan at different time intervals during 2008-2010. Precipitation and relative humidity were correlated with dengue fever during 2011-2013. However, 3-5-month lagged relative humidity was the strongest explanatory variable for the incidence of dengue.

Conclusion: Dengue transmission appears sensitive to climatic variability. Elucidating the role of climatic factors in dengue fever helps in risk assessment and prevention of epidemics.

Keywords: dengue, infection control, incidence, climate, Port Sudan

Citation: Noureldin El; Shaffer L. Role of climatic factors in the incidence of dengue in Port Sudan City, Sudan. East Mediterr Health J. 2019;25(12):852860. https://doi.org/10.26719/emhj.19.019

Received: 29/08/17; accepted: 12/02/18

Copyright @ World Health Organization (WHO) 2019. Some rights reserved. This work is available under the CC BY-NC-SA 3.0 IGO license (https:// creativecommons.org/licenses/by-nc-sa/3.0/igo).
\end{abstract}

\section{Introduction}

Dengue is a viral disease transmitted to humans by the bite of infected females of the main mosquito vector $\mathrm{Ae}$ des aegypti and to a lesser extent Aedes albopictus (1). Traditionally, the World Health Organization (WHO) has classified dengue into three categories according to severity: dengue fever, dengue haemorrhagic fever and dengue shock syndrome (2). The clinical characteristics of dengue are sudden onset of severe fever, pain behind the eyes (retro-orbital), nausea, swollen lymph nodes (lymphadenopathy), intense headache, muscle pain (myalgia), gastrointestinal problems, joint pain and rash (3). Dengue haemorrhagic fever and dengue shock syndrome cause lethal complications that include severe haemorrhage, plasma leakage, organ impairment, fluid accumulation, and respiratory distress (3).

Dengue fever is considered by WHO to be the most important mosquito-borne viral disease. Dengue incidence has increased > 10-fold throughout the last 3 decades, with a currently estimated 50-100 million annual cases distributed over $>100$ countries. WHO has advocated the development of preventive and proactive measures to limit dengue transmission and outbreaks (4).

Previous investigators have examined factors that affect populations of Ae. aegypti and subsequent dengue fever incidence. Unplanned urbanization and climatic factors, including high temperatures and rainfall, might contribute to epidemics of dengue $(5,6)$. Aedes mosquitoes are found in urban settings, especially in tropical areas, where they maintain a sustainable relationship with humans, which has led to re-emergence of dengue virus infections (7). Climatic factors of temperature, rainfall and humidity are thought to have the most potential to affect the maturation periods, habitats, survival time and vectorial capacity of Aedes mosquitoes (8). Researchers from various geographic areas have reported significant associations between temperature, relative humidity, precipitation and dengue distribution and transmission, e.g., India (9), Thailand (10), Malaysia (11), Viet Nam (12), Philippines (13), Indonesia (14), and Singapore (15). For example, Karim et al. (16) in Dhaka, Bangladesh, found positive significant correlations between the 2-month-lagged relative humidity, rainfall, maximum temperature, and the reported monthly dengue cases. Other researchers reported no effect of climatic factors on the incidence of dengue fever/dengue haemorrhagic fever $(15,17)$. Also, in Central Visayas, Philippines, Picardal and Elnar (18) found no correlation between dengue cases and rainfall or temperature. Given these variable findings, it is possible that the effects of climatic factors such as precipitation, temperature and relative humidity may depend on the normal conditions of a particular geographic area.

In the last 2 decades, Port Sudan City has witnessed several dengue outbreaks, and the incidence of dengue 
was estimated as 94 cases per 10000 during the 2010 outbreak in which 3765 cases were reported $(19,20)$. There have been no ecological investigations of the role of climatic factors on the incidence of dengue fever in Sudan, particularly in Port Sudan, where most of the dengue fever/dengue haemorrhagic fever in the country has occurred. Since climatic factors are thought to affect the population of Ae. aegypti and dengue fever incidence, this information could be helpful in planning for public health preventive and control measures in this region.

The present study aimed to describe the temporal relationship between climatic factors (maximum and minimum temperatures, relative humidity or rainfall) and the incidence of dengue fever in Port Sudan City, Sudan, during 2008-2013.

\section{Methods}

\section{Study design and setting}

This study was an ecological analysis of the association between climatic factors and dengue fever incidence in Port Sudan City, Sudan, for the period 2008-2013. Port Sudan is located on the Red Sea and has an arid (low precipitation) and humid (Mediterranean) climate. The mean maximum temperature is around $40^{\circ} \mathrm{C}$ in summer (June-September) and the mean minimum temperature is $20.5^{\circ} \mathrm{C}$ in winter (November-March). Total annual precipitation is $76.1 \mathrm{~mm}$ in the rainy season (October-January), and the annual average relative humidity is $63 \%$ $(19,21)$.

\section{Sampling frame}

The sampling frame was the monthly secondary data (datasets) of the dengue fever/dengue haemorrhagic fever cases and the climatic information from 2008 to 2013. The time period 2008-2013 was chosen because it contained complete information on dengue fever/dengue haemorrhagic fever cases. The sampling frame included the monthly number of dengue fever/dengue haemorrhagic fever cases, relative humidity, temperature (maximum and minimum), and rainfall (precipitation). The data of weekly dengue cases were obtained from the Department of Epidemiology, Ministry of Health, Red Sea State, Sudan. All dengue fever cases are required to be reported to the health authorities in Port Sudan, namely the Department of Epidemiology, and all suspected cases are sent to local laboratories for confirmation of dengue infection. Laboratory tests that are dengue positive are sent to the National Public Health Laboratory in Khartoum for confirmation. The data were captured in an electronic dataset. The climatic variables were obtained from the Sudan Meteorological Authority, which collects data on temperature, relative humidity and rainfall in real time through its widely distributed sentinel meteorological stations including one in Port Sudan.

\section{Data analysis}

It was noted from the preliminary graphic analysis that the number of dengue cases was higher during 2008 through to most of 2010 and then declined significantly in 2011-2013. The reason behind that was the strong epidemiological and entomological surveillance and control measures undertaken by the Ministry of Health, Red Sea State to deal with the outbreak that started in June 2010 and continues to the present (Department of Epidemiology, Red Sea State, personal communication, 2014). Therefore, for the purposes of analysis the study period was split into 2008-2010 and 2011-2013.

Wilcoxon rank sum tests were utilized to examine the association between number of dengue fever/ dengue haemorrhagic fever cases and the following factors: minimum temperature, maximum temperature, relative humidity, and rainfall for 1-6 months' lag time, according to cutoff values for the climatic factors that were identified from preliminary graphic analysis, which indicated threshold relationships between the climatic factors and dengue fever incidence, rather than doseresponse relationships. Lag time indicated the number of months between the time when dengue fever cases were reported and the pattern of the climatic factor of interest. The unit of time was months, as weather data were available only in monthly units. Multiple linear regression was used to determine which independent variables still influenced the monthly number of dengue fever/dengue haemorrhagic fever cases during lag time of 1-6 months after taking into account the other climatic factors. SPSS version 20 was used for statistical analysis.

\section{Results}

Figures 1-4 illustrate the relationships between precipitation, relative humidity and maximum and minimum temperature and the number of dengue fever/dengue haemorrhagic fever cases for 2008-2010 and 2011-2013. For each climatic factor, the histogram bars show the median number of dengue fever/dengue haemorrhagic fever cases according to whether the monthly average factor was above or below the threshold value derived from graphical analysis (vertical axis), and the time lag for that particular climatic factor (horizontal axis). The number on the horizontal axis represents the number of months between the measurement of the climatic factor and the reporting of the dengue fever/dengue haemorrhagic fever cases, with negative numbers to indicate that the climatic measurement took place prior to the occurrence of the dengue fever/dengue haemorrhagic fever cases. It should be noted that although the shape of the trends for Figures 1-4 are similar for the two time periods, the total number of cases was smaller during 2011-2013.

\section{Precipitation}

Although there were some differences in the number of dengue fever/dengue haemorrhagic fever cases according to whether there was any rainfall 4-6 months prior to the dengue fever/dengue haemorrhagic fever reporting month, precipitation was not correlated with dengue incidence during any of the 6 months lag time during 20082010 (all $P>0.05$, Figure 1). Nevertheless, the incidence of dengue cases at average precipitation $>0$ exceeded that of 
Figure 1 Number of dengue fever/dengue haemorrhagic fever cases according to the occurrence of precipitation and number of months prior to reporting

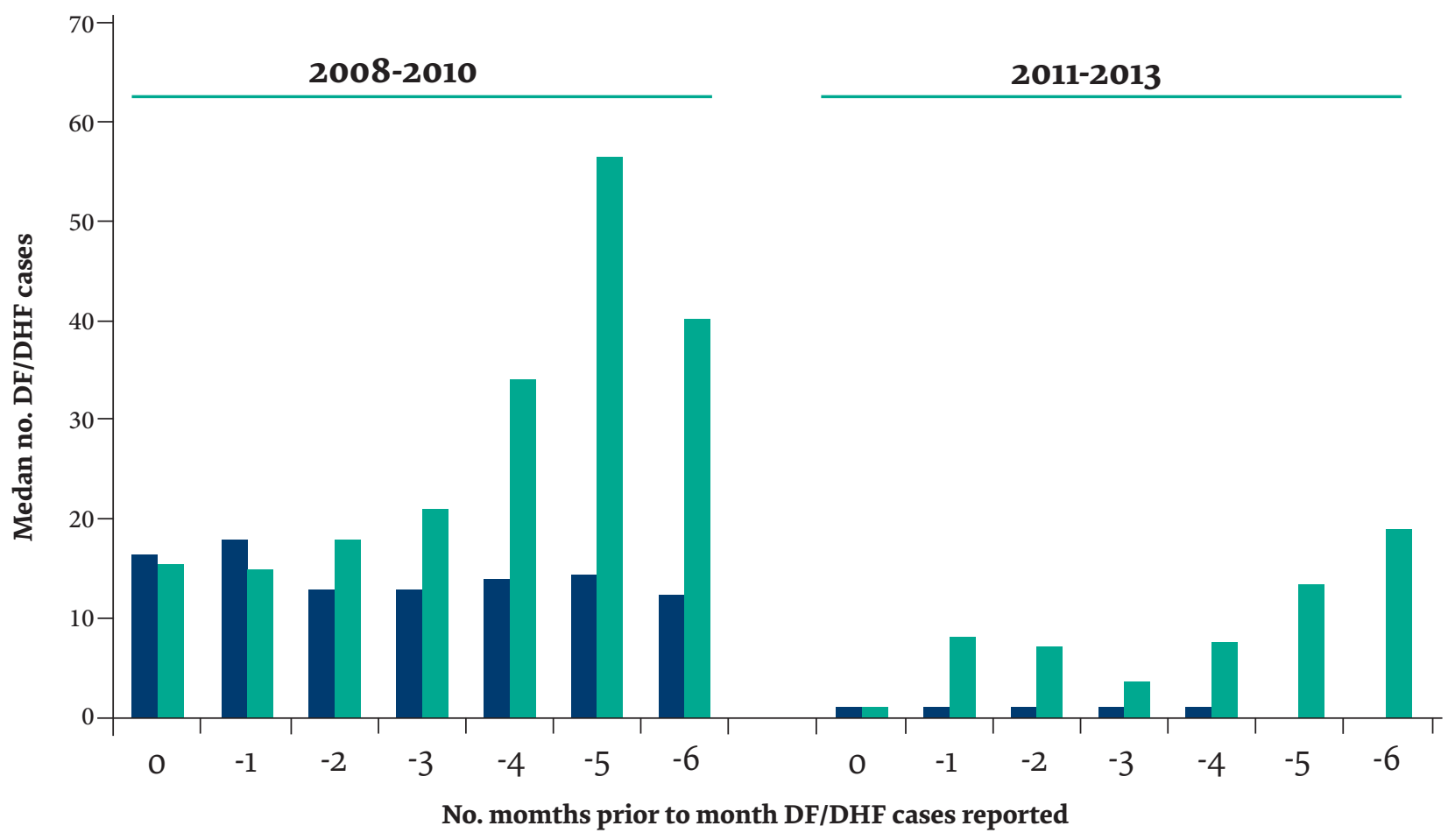

No precipitation

Precipitation

dengue incidence when there was no recorded precipitation in all months except 0 and 1 month prior to the dengue fever/dengue haemorrhagic fever reporting month during 2008-2010 (Figure 1). In contrast, for 2011-2013, although the total number of dengue fever cases was lower, the occurrence of any precipitation during 5 or 6 months prior to the dengue fever reporting month was associated with a significantly elevated number of cases $(P=0.0433$ and 0.0298 , respectively). The shape of this trend is similar to that observed for the time period 2008-2010 in that the difference in number of dengue fever/dengue haemorrhagic fever cases between conditions of no precipitation versus at least some precipitation was most extreme at 4, 5 and 6 months prior to the dengue fever/dengue haemorrhagic fever reporting period.

\section{Relative humidity}

For 2008-2010, relative humidity started to show a positive association with dengue fever/dengue haemorrhagic fever at the 3-month lag time $(P=0.0025)$ and continued at 4 months $(P=0.0003)$ and 5 months $(P=0.0037)$ (Figure 2$)$. The highest occurrence of average (rather than median) number of dengue cases correlated with high relative humidity at the 3-month (246.4), 4-month (253.8) and 5-month (226.4) lag times. Relative humidity $<56 \%$ compared to $\geq 56 \%$ during $3-5$ months prior to the dengue fever/dengue haemorrhagic fever reporting month produced the largest difference between numbers of cases during 2008-2010. For 2011-2013, relative humid- ity $\geq 56 \%$ was significantly associated with an increased number of dengue fever cases only at 3 months prior to the reporting of those cases, with 21.8 average (rather than median) monthly reported dengue cases compared to 6.2 cases when relative humidity was $<56 \%(P=0.0202)$.

\section{Maximum temperature}

In 2008-2010, maximum temperature was significantly correlated with dengue at the 2-, 3- and 4-month lag times $(P=0.0196,0.0027$ and 0.0365 , respectively. (Figure 3 ). It appeared that average maximum temperature $<35^{\circ} \mathrm{C}$ favoured high incidence of dengue, with average (rather than median) numbers of dengue fever/dengue haemorrhagic fever cases of 220.8, 217.4 and 186.2, respectively, compared to only $26.5,18.7$ and 49.1 when the average maximum temperature was $\geq 35^{\circ} \mathrm{C}$. No significant trends were seen with respect to maximum temperature for 2011-2013 (all $P>0.05)$.

\section{Minimum temperature}

The minimum temperature was significantly correlated with dengue at the 1-, 2-, 3- and 4-month lag times ( $P$ $=0.0427,0.0012,0.0024$ and 0.0215 , respectively) during 2008-2010 (Figure 4). The incidence of dengue was significantly increased when the minimum temperature was < $25^{\circ} \mathrm{C}$ compared to $\geq 25^{\circ} \mathrm{C}$. No significant trends were seen with respect to minimum temperature for 2011-2013 (all $P>0.05)$. 
Figure 2 Number of dengue fever/dengue haemorrhagic fever cases according to relative humidity and number of months prior to reporting

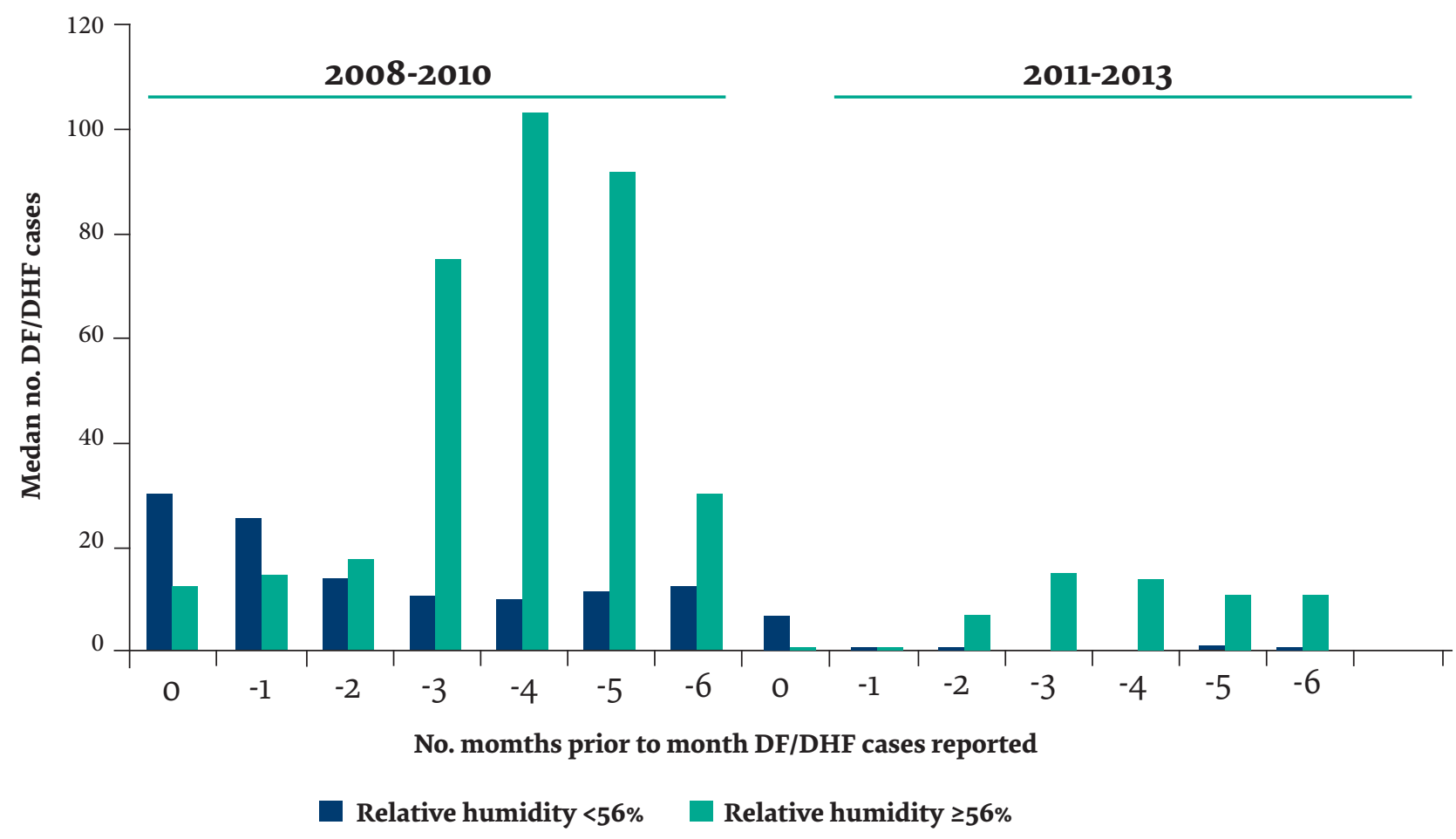

\section{Association of climatic factors with dengue fever/dengue haemorrhagic fever incidence}

Multiple linear regression modelling was done to determine whether all of the climatic factors individually associated with an increase in dengue fever cases remained independently associated after other climatic factors were taken into account. The final regression model is displayed in Table 1. Only relative humidity < $56 \%$ versus $\geq 56 \%$ at 3,4 and 5 months prior to the dengue fever reporting month remained independently associated with the number of dengue fever cases reported. The interaction term in the model indicates that this effect of relative humidity was greater during 2008-2011 than 2011-2013. The results also indicate that the other climatic factors do not have any significant relationship with dengue fever cases after controlling for relative humidity. In other words, the minimum temperature, maximum temperature and precipitation were strongly correlated with relative humidity, and once we took into account relative humidity, they did not add any information for predicting the number of dengue fever cases.

\section{Discussion}

Overall, this study suggested that relative humidity $\geq$ $56 \%$ was strongly and independently associated with an increased number of dengue fever/dengue haemorrhagic fever cases 3-5 months later. The lower number of cases reported during 2011-2013 also suggested that the control measures put in place in 2010 by the Ministry of Health, Red Sea State, were effective. Precipitation in 2008-2010 showed no significant association with dengue incidence, probably because most of the breeding sites were available indoors for Ae. aegypti mosquitoes, and this vector was therefore dependent on the behaviour of humans rather than precipitation for their survival and development $(22,23)$. In Philippines, Singapore and Indonesia, outbreaks of dengue have occurred even in dry seasons, possibly due to practices of water storage (24). This may partly explain the weak impact of precipitation compared to other climatic factors on the dengue cases. However, the relationship between precipitation and Ae. aegypti population is complex (25).

We showed that precipitation at 5 and 6 months' time lag was positively correlated with

Table 1 Linear regression describing relationship between relative humidity and monthly frequency of dengue fever/dengue haemorrhagic fever cases, 2008-2013 
Figure 3 Number of dengue fever/dengue haemorrhagic fever cases according to maximum temperature and number of months prior to reporting

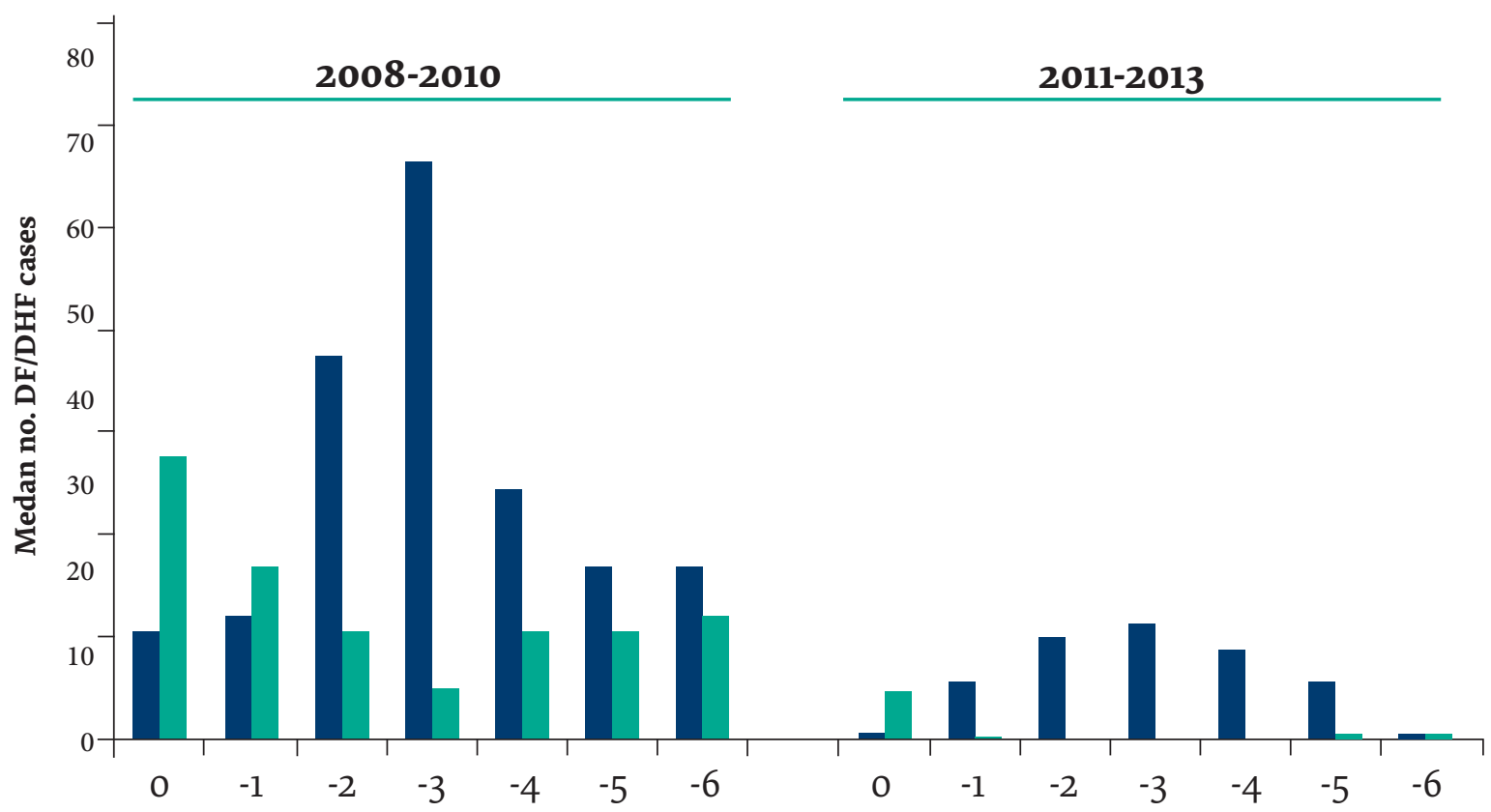

No. momths prior to month DF/DHF cases reported

$\operatorname{Tmax}<35^{\circ}$

dengue cases in 2011-2013. This is in line with the findings of Hii et al. (26), who found a linear increase in dengue cases in Singapore at a time lag of 5-20 weeks after elevated precipitation. Vu et al. (12) reported 0-3 months' time lag after precipitation and before the incidence of dengue, while Rubio-Palis et al. (17) identified 4 months as the critical time point. Furthermore, it has been found that the abundance of A. aegypti adults and larvae in Port Sudan is directly proportional to relative humidity and precipitation (27).

Relative humidity $\geq 56 \%$ was significantly associated with dengue cases at 3-5 months' lag time in 2008-2010, and at 3 months' lag time in 2011-2013. Corroborating results have been reported by Ahmed (27), who found that the population density of Ae. aegypti larvae in Jeddah was large at $55.4 \%$ relative humidity and small at $45.4 \%$. Banu et al. (28) in Dhaka, Bangladesh, also revealed that relative humidity was positively correlated with dengue incidence at a 4-month lag time. Relative humidity is "the amount of atmospheric moisture present relative to the amount that would be present if the air were saturated" (http://graphical.weather.gov/definitions/defineRH. html) and is a function of temperature: relative humidity increases as temperature decreases. As relative humidity has its effects on all stages of the mosquito life cycle, its combined impact with temperature significantly affects the survival rate of the mosquito, number of blood meals, and eventually its capacity to become infected and transmit dengue (29).

In our study, maximum temperature $<35^{\circ} \mathrm{C}$ in $2008-$ 2010 was positively associated with dengue incidence at lag time of 2-4 months before the incidence of dengue.
$\operatorname{Tmax} \geq 35^{\circ}$

This is in accordance with the work of Depradine and Lovell (30), who found a 4-month time lag between maximum temperature and dengue incidence. Moreover, the present study revealed that average maximum temperature $<35^{\circ} \mathrm{C}$ favoured high incidence of dengue in Port Sudan. Similar results of an association between temperature $>26^{\circ} \mathrm{C}$ and dengue risk have been reported (26).

Minimum temperature was significantly correlated with dengue at 1-4 months' lag time in 2008-2010. Several researchers found a similar association with slight differences. For example, Depradine and Lovell (30) reported a 3-month lag time between minimum temperature and dengue incidence, and Gomes et al. (31) reported a 1-month lag. Honório et al. (32) found a positive effect of air temperature of $22-24^{\circ} \mathrm{C}$ on the development of $\mathrm{A}$. aegypti but no effect was evident above $24^{\circ} \mathrm{C}$ in Rio de Janeiro, Brazil.

The general trends in our study seem to be that higher relative humidity at 3-5 months prior to the reporting month for dengue fever, and then lower or more moderate minimum and maximum temperatures 2-4 months before are related to large increases in the number of dengue fever cases. This is in line with the findings of Chen et al. (33), who suggested that warmer temperature at 3-months' lag, and high humidity with high mosquito population increased the rate of transmission of dengue fever in Southern Taiwan.

Although our multiple linear regression showed that the primary factor involved with dengue fever 
Figure 4 Number of dengue fever/dengue haemorrhagic fever cases according to minimum temperature and number of months prior to reporting

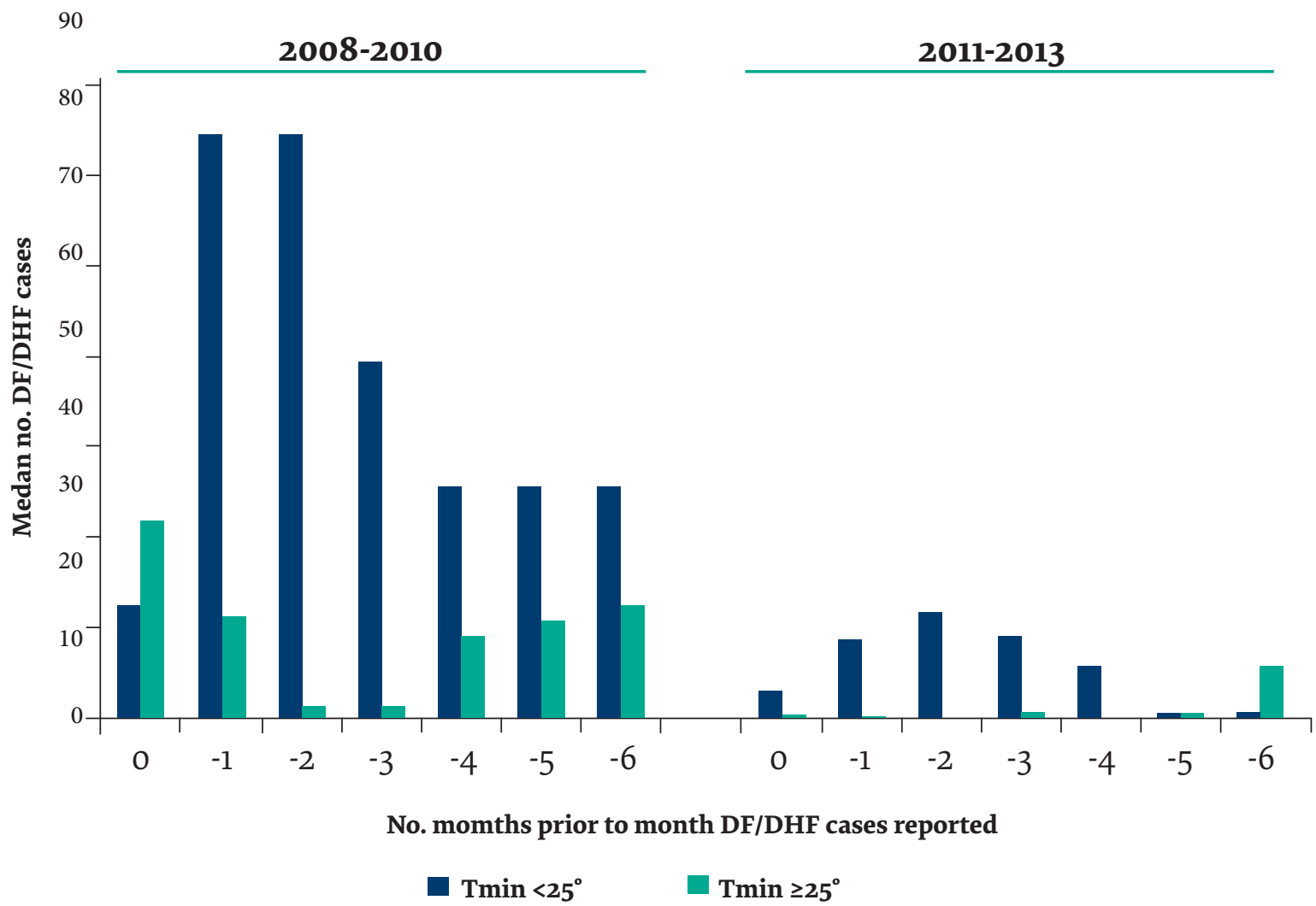

incidence was relative humidity, it seems that relative humidity is closely linked to moderate temperatures. Moderate temperatures allow for higher relative humidity and thus optimum conditions for Ae. aegypti to reproduce. Valsson and Bharat (34) argued that there is a negative correlation between temperature and relative humidity. Therefore, the relationship between relative humidity and minimum/maximum temperatures is not necessarily one of confounding, but that minimum/ maximum temperatures are precursors to, or preservers of, the level of relative humidity.

The time lag seems to suggest that it takes a few months of favourable climatic conditions to build up a large enough mosquito population that a sufficient number of people would be exposed to dengue virus. This could happen through the effect of these climatic factors on the life cycle of the dengue virus and its vector. Climatic factors influence all the developmental stages of the mosquito until it becomes an adult, then they affect virus replication and its incubation period inside the mosquito (the extrinsic incubation period) and humans (intrinsic incubation period). The latter might culminate in dengue outbreaks that may in turn be represented by a cumulative time lag $(29,35)$.

The lag between climatic factors data and dengue incidence data differs depending on the corresponding lag between mosquito life stage and the expression of clinical symptoms. In the case of minimum temperature, this lag is expected to be shorter because minimum temperature is often associated with mortality in adult mosquitoes, and longer in case of high relative humidity, which influences the hatching and survival of adult mosquitoes. Mean temperature is usually associated with all biological cycles of the vector Ae. aegypti, which take more time to affect the incidence of dengue (35). These patterns were observed in the present study.

The present study had some limitations. The cutoffs used for some of the analyses were based on visual inspection of the scatterplots. It would be beneficial to assess whether the findings of the present study could be replicated in another dataset based on a climate similar to that of Port Sudan City. In most low-income countries, dengue cases are often under- or overreported. Moreover, those reported dengue cases might be affected by documentation of subclinical cases, public health systems availability, and case definition. Based on this, the aforementioned factors should be considered prior to identifying any associations between dengue transmission and climatic factors. Finally, this ecological analysis did not consider socioeconomic or other factors that may influence DF incidence; therefore, this study could not examine their role relative to that of climatic factors.

\section{Conclusion}

Among other factors, dengue transmission in Port Sudan appears sensitive to variability in climate. Other factors 
may include, but are not limited to, human population level, mobility, socioeconomic status, population's immune status, and human-mosquito interaction. Increasing urbanization around Port Sudan has led to a rise in population. This suggests continued likelihood of dengue fever outbreaks and the need to develop prevention and control mechanisms. As a port, dengue outbreaks in Port Sudan may represent dangers to surrounding cities, or of transporting dengue to other locations via ships. It is important to elucidate the role of climatic factors in dengue transmission because it helps in risk assessment of epidemics and facilitates preventive actions. This is especially relevant given that time lags of 2-5 months were identified, which allows for adequate planning. Future studies should integrate the analysis of climatic and nonclimatic factors that maintain a sustainable viral circulation, such as human population size, human renewal rate, household infestation, and ratio of mosquito vectors per person.

The results of this study should help to strengthen dengue surveillance and control programs in Port Sudan City, and to establish climate-based outbreak alert and early warning systems for dengue in the city and Sudan as a whole. Health authorities can synchronize efforts across meteorological departments, research institutions, and national surveillance systems to develop and integrate a climate-based dengue forecasting system.

\section{Funding: None.}

Competing interests: None declared.

\section{Rôle des facteurs climatiques dans l'incidence de la dengue dans la ville de Port Soudan, Soudan}

\section{Résumé}

Contexte : Des flambées de dengue sont survenues dans la ville de Port Soudan (Soudan) au cours des deux dernières décennies. Les facteurs climatiques peuvent jouer un rôle dans l'incidence de cette maladie.

Objectif : La présente étude avait pour objectif de décrire la relation entre les facteurs climatiques et l'incidence de la dengue à Port Soudan au cours de la période 2008-2013.

Méthodes : La présente étude écologique comprenait l'analyse de données secondaires sur les cas de dengue et des informations climatiques afin d'étudier les facteurs climatiques qui permettent de prévoir l'incidence de la dengue. Le test de la somme des rangs de Wilcoxon et la régression linéaire multiple ont permis d'examiner l'association entre le nombre de cas de dengue et les facteurs climatiques pendant des périodes de 1 à 6 mois.

Résultats : L'humidité relative et les températures maximales et minimales ont été corrélées avec l'incidence de la dengue à Port Soudan à différents intervalles de temps au cours de la période 2008-2010. Les précipitations et l'humidité relative ont été corrélées avec la dengue au cours de la période 2011-2013. Cependant, l'effet différé de l'humidité relative 3 à 5 mois plus tard était la variable explicative la plus forte pour l'incidence de la dengue.

Conclusion : La transmission de la dengue semble sensible à la variabilité climatique. L'élucidation du rôle des facteurs climatiques dans la dengue contribue à l'évaluation des risques et à la prévention des épidémies.

$$
\text { الصور العوامل المناخية في الإصابة بحمى الضنك في مدينة بورتسودان في السودان }
$$

الخلفية: حدثت أوبئة حىى الضنك في مدينة بورتسودان بالسودان خلال العقدين الأخيرين. وربها يكون للعوامل المناخية دور في الإصابة بحمى

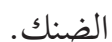

الأهداف: هدفت هذه الدراسة إلى وصف العلاقة بين العوامل المناخية ومعدلات الإصابة بحمى الضنك في مدينة بورتسودان خلال الفترة من $r \cdot 1 r$ r.

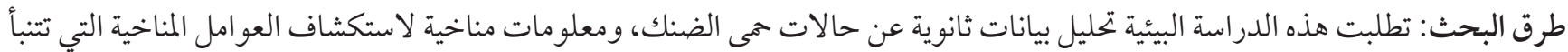

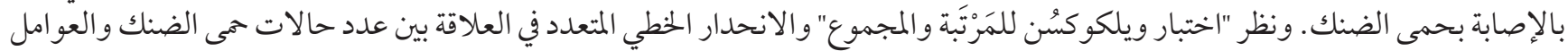
المناخية خلال فارق زمني يتراوح من شهر إلى 7 أشهر.

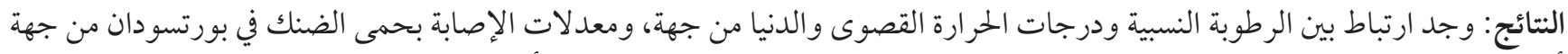

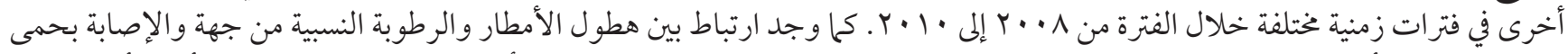

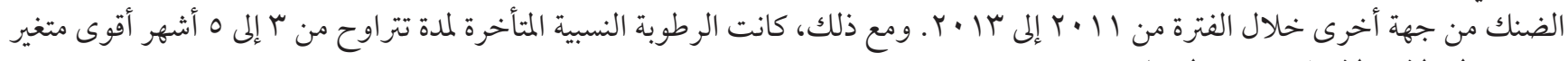

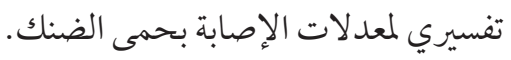

الاستنتاج: يبدو أن انتقال عدوى حمى الضنك يتأثر بتقلب المناخ. ويساعد توضيح دور العوامل المناخية في الإصابة بحمى الضنك إنك على تقدير المخاطر والوقاية من الأوبئة. 


\section{References}

1. Dengue: guidelines for diagnosis, treatment, prevention and control: new edition. Geneva: World Health Organization; 2009 (WHO/HTM/NTD/DEN/2009.1; https://apps.who.int/iris/bitstream/handle/10665/44188/9789241547871_eng.pdf;jsessionid=9D1A2B484148F3953ED915F732DC598C?sequence=1, accessed 16 April 2019).

2. Dengue haemorrhagic fever: diagnosis, treatment, prevention and control. 2nd edition. Geneva: World health Organization; 1997 (https://apps.who.int/iris/bitstream/handle/10665/41988/9241545003_eng.pdf?sequence=1\&isAllowed=y, accessed 16 April 2019).

3. Dengue [website]. World Health Organization (http://apps.who.int/tdr/svc/diseases/dengue, accessed 16 April 2019).

4. Report of a WHO technical working group meeting on dengue prevention and control. Geneva: World Health Organization; 2012 (http://www.who.int/denguecontrol/Summary_Technical_working_group_meeting.pdf?ua=1 2012, accessed 16 April 2019).

5. Crowell G, Cazelles B, Broutin H, Munayco CV. The influence of geographic and climate factors on the timing of dengue epidemics in Peru, 1994-2008. BMC Infect Dis. 2011 Jun 8;11:164. http://dx.doi.org/10.1186/1471-2334-11-164 PMID:21651779

6. Banu S, Hu W, Hurst C, Tong S. Dengue transmission in the Asia-Pacific region: impact of climate change and socio-environmental factors. Trop Med Int Health. 2011 May;16(5):598-607. http://dx.doi.org/10.1111/j.1365-3156.2011.02734 PMID:21320241

7. Su GL. Correlation of climatic factors and dengue incidence in Metro Manila, Philippines. Ambio. 2008 Jun;37(4):292-294. PMID:18686509

8. Wu PC, Lay JG, Guo HR, Lin CY, Lung SC, Su HJ. Higher temperature and urbanization affect the spatial patterns of dengue fever transmission in subtropical Taiwan. Sci Total Environ. 2009 Mar 15;407(7):2224-2233.

9. Sankari T, Hoti SL, Bhubonchandra Singh Th, Shanmugavel J. Outbreak of dengue virus serotype-2 (DENV-2) of Cambodian origin in Manipur, India - association with meteorological factors. Ind J Med Res. 2012 Oct;136(4):649-665. PMID:23168706

10. Promprou S, Jaroensutasinee M, Jaroensutasinee K. Climatic factors affecting dengue haemorrhagic fever incidence in Southern Thailand. Dengue Bull. 2005 Dec;29:41-48.

11. 11. Nazri CD, Abu Hassan A, Abd Latif Z, Rodziah I. Impact of climate and land use variability based on dengue epidemic outbreak in Subang Jaya. In: Proceedings of Humanities, Science and Engineering (CHUSER), 2011 IEEE Colloquium, Penang, Malaysia, 5-6 December, 2011.

12. Vu HH, Okumura J, Hashizume M, Tran DN, Yamamoto T. Regional differences in the growing incidence of dengue fever in Vietnam explained by weather variability. Trop Med Health. 2014 Mar;42(1):25-33. http://dx.doi,org/10.2149/tmh.2013-24 PMID:24808744

13. Opena ELL, Teves FG. Climate and the incidence of dengue fevers in Iligan City, the Philippines. Asia-Pacific J Soc Sci. 2011(Special Issue):114-131.

14. Zulfaidah PG, Nobukazu N. Climatic variability and dengue hemorrhagic fever incidence in Nganjuk district, East Java Indonesia. Acta Biologica Malaysiana. 2013;2:31-39.

15. Wang ZC, Hoong MH, Martin LL, Gary KK. Delayed effects of climate variables on incidence of dengue in Singapore during 2000-2010. APCBEE Procedia 2012;1:22-26.

16. Karim MN, Munshi SU, Anwar N, Alam MS. Climatic factors influencing dengue cases in Dhaka city: A model for dengue prediction. Indian J Med Res. 2012 Jul;136(1):32-39. PMID:22885261

17. Rubio-Palis Y, Pérez-Ybarra LM, Infante-Ruíz M, Comach G, Urdaneta-Márquez L. Influence of climatic variables on dengue cases and abundance of Aedes aegypti (Diptera: Culicidae) in Maracay, Venezuela. Boletín de Malariología y Salud Ambiental. $2011 \operatorname{Dec} ; 51(2): 145-157$.

18. Picardal JP, Elnar AR. Rainfall, temperature and the incidence of dengue in Central Visayas, Philippines are not correlated. CNU J Higher Educ. 2012;661-70.

19. Seidahmed OME, Hassan SA, Soghaier MA, Siam HAM, Ahmed FTA, Elkarsany MM et al. Spatial and temporal patterns of dengue transmission along a Red Sea coastline: a longitudinal entomological and serological survey in Port Sudan City. PLoS Negl Trop Dis. 2012; 6(9):e1821. http://dx.doi.org/10.1371/journal.pntd.0001821 PMID:23029582

20. Seidahmed OME, Siam HAM, Soghaier MA, Abubakr M, Osman HA, Abd Elrhman LS, et al. Dengue vector control and surveillance during a major outbreak in a coastal Red Sea area in Sudan. East Mediterr Health J. 2012 Dec;18(12):1217-1224. PMID:23301396

21. Sudan [website] World Meteorological Organization (http://www.worldweather.org/085/c01535.htm, accessed 16 April 2019).

22. Saifur RGM, Dieng H, Hassan AA, Salmah MRC, Satho T, Miake F, et al. Changing domesticity of Aedes aegypti in Northern Peninsular Malaysia: reproductive consequences and potential epidemiological implications. PLoS One. 2012;7(2):e30919. http:// dx.doi.org/10.1371/journal.pone.0030919 PMID:22363516

23. Moore CG, Cline BL, Ruiz-Tiben E, Lee D, Romney-Joseph H, Rivera-Correa E. Aedes aegypti in Puerto Rico: environmental determinants of larval abundance and relation to dengue virus transmission. Am J Trop Med Hyg. 1978 Nov; 27(6):1225-1231. PMID:727328

24. Aiken SR, Frost DB, Leigh CH. Dengue hemorrhagic fever and rainfall in Peninsular Malaysia: some suggested relationships. Soc 
Sci Med D Med Geog. 1980 Sep;14(3):307-316. https://doi.org/10.1016/0160-8002(80)90043-X

25. Gage KL, Burkot TR, Eisen RJ, Hayes EB. Climate and vector-borne diseases. Am J Prev Med. 2008 Nov; 35(5):436-450. PMID: 18929970.

26. Hii YL, Rocklöv J, Nawi Ng, Tang CS, Pang FY, Sauerborn R. Climate variability and increase in intensity and magnitude of dengue incidence in Singapore. Glob Health Action. 2009 Nov 11;2 http://dx.doi.org/0.3402/gha.v2io.2036 PMID:20052380

27. Ahmed YE. The effect of climatic factors on abundance of Aedes aegypti L. and transmission of dengue fever in Port Sudan (Sudan) and Jeddah (Saudi Arabia) [thesis]. University of Khartoum; 2014.

28. Banu S, Hu W, Hurst C, Tong S. Dengue transmission in the Asia-Pacific region: impact of climate change and socio-environmental factors. Trop Med Int Health. 2011 May;16(5):598-607. http://dx.doi,org/10.1111/j. 2011; 1365-3156.2011.02734 PMID:21320241

29. McMichael A, Haines A, Slooff R, Kovats R. Climate change and human health: an assessment by a task group on behalf of the World Health Organization. Geneva: World Health Organization, World Meteorological Association, United Nations Environment Programme; 1996 (http://www.who.int/iris/handle/10665/62989, accessed 16 April 2019).

30. Depradine C, Lovell E. Climatological variables and the incidence of Dengue fever in Barbados. Int J Environ Health Res. 2004 Dec;14(6):429-441. PMID:15545038

31. Gomes AF, Nobre AA, Cruz OG. Temporal analysis of the relationship between dengue and meteorological variables in the city of Rio de Janeiro, Brazil, 2001-2009. Cad Saúde Pública. 2012 Nov;28(11):2189-97. PMID:23147960

32. Honório NA, Codeço CT, Alves FC, Magalhães M. Temporal distribution of Aedes aegypti in different districts of Rio de Janeiro, Brazil, measured by two types of traps. J Med Entomol. 2009 Sep;46(5):1001-14.

33. Chen SC, Liao CM, Chio CP, Chou HH, You SH, Cheng YH. Lagged temperature effect with mosquito transmission potential explains dengue variability in Southern Taiwan: insights from a statistical analysis. Sci Total Environ. 2010 Sep 1;408(19):4069-75. http://dx.doi.org/10.1016/j.scitotenv.2010.05.021 PMID:20542536

34. Valsson S, Bharat A. Impact of air temperature on relative humidity - a study. Architecture Time Space People. 2011 Feb;38-41.

35. Gharbi M, Quenel P, Gustave J, Cassadou S, La Ruche G, Girdary L, et al. Time series analysis of dengue incidence in Guadeloupe, French West Indies: forecasting models using climate variables as predictors. BMC Infect Dis. 2011 Jun 9;11:166. http:// dx.doi.org/10.1186/1471-2334-11-166 PMID:21658238 